these diagnoses. No doubt the transitory nature of the dizziness, and the patients' perfect health between attacks of dizziness must have contributed to the tendency to consider the attacks psychogenic. Despite the length of the history of dizzy episodes in many of the patients and the development of generalised seizures in seven, anticonvulsant medication was extremely effective. It is thus clearly of great practical importance to consider epilepsy in the differential diagnosis of episodic dizziness or vertigo, especially in young people.

\section{References}

${ }^{1}$ Jackson H. Diagnosis of epilepsy. Medical Times and Gazette 1879;1:29.
2 Gowers WR. The borderlands of epilepsy. London: Churchill, 1907:40-75.

${ }^{3}$ Currie S, Heathfield KWG, Henson RA, et al. Clinical course and prognosis of temporal lobe epilepsy. Brain 1971;94:173-90.

${ }^{4}$ Penfield W. Vestibular sensation and the cerebral cortex. Ann Otol Rhinol Laryngol 1957;66:691-8.

5 Williams DJ. Central vertigo. Proc $R$ Soc Med 1967;60:961-4.

${ }^{6}$ Behrman S, Wyke BD. Vestibulogenic seizures. Brain 1958;81:529-41.

7 Drachman DA, Hart CW. An approach to the dizzy patient. Neurology (Minneap) $1972 ; 22: 323-34$.

${ }^{8}$ Hughes MR, Drachman DA. Dizziness, epilepsy and the EEG. 7 Nerv Ment Dis $1977 ; 38: 431-5$.

9 Pedersen E, Jepson O. Epileptic-vertigo. Acta Psychiatr Neurol Scand [Suppl] 1956;108:301-10.

${ }^{10}$ Evistar L, Evistar A. Vertigo in children; differential diagnosis and treatment. Pediatrics 1977;59:833-8.

\title{
The Cardiff Cervical Cytology Study: prevalence of cytological grades and initial histological findings
}

\author{
DAVID M D EVANS， BRYAN M HIBBARD， JANE M JONES， PETER SWEETNAM
}

\begin{abstract}
Among 45266 women in the Cardiff Cervical Cytology Survey the peak prevalence of suspicious or positive smears was $11 \cdot 2 / 1000$ at age 45-50 years and of dyskaryosis $10 \cdot 2 / 1000$ at age 25-29. A suspicious or positive cytological picture at prevalence testing was associated with occult or clinical invasion in $24 \%$ of cases, and only $4 \%$ of patients with suspicious or positive smears were normal histologically. When dyskaryosis was detected in the prevalence test $20 \%$ had carcinoma in situ or microinvasion and $3 \%$ had occult or clinically invasive carcinoma. One hundred and twenty-nine $(51 \%)$ women with dyskaryotic smears did not have a biopsy initially (that is, within two years of the prevalence test), but they were followed up at regular intervals. Subsequently 15 of the 129 gave smears consistently dyskaryotic or worse cytologically and were subjected to biopsy. Of these, two showed dysplasia, 12 carcinoma in situ, and one clinically invasive carcinoma.

These findings emphasise the need for repeat cytological or histological examination in any woman with evidence of dyskaryosis in a cervical smear.
\end{abstract}

\section{Introduction}

The benefits of screening programmes for cervical neoplasia are still not fully evaluated. The optimum strategy, particularly in terms of frequency of screening and the age at which screening should first be done, is uncertain and will remain so until more is known about the natural history of cancer.

This paper, based on data from the Cardiff Cervical Cytology Study, ${ }^{12}$ describes the prevalence of the various cytological patterns and the histological findings within two years of the prevalence test.

\footnotetext{
Welsh National School of Medicine and South Glamorgan Area Health Authority, Cardiff CF4 4XN

DAVID M D EVANS, MD, FRCPATH, consultant pathologist

BRYAN M HIBBARD, MD, FRCOG, professor of obstetrics and gynaecology JANE M JONES, FRCOG, medical assistant

Medical Research Council Epidemiology Unit, Cardiff PETER SWEETNAM, MSC, statistician
}

\section{Subjects and methods}

The study was based on a defined population of all "ever-married" women aged 25-69 resident within the Cardiff City area. Methods, enumeration and definition of the population, and initial acceptance rates have been described. ${ }^{2}$ The total defined population was 70869 women, of whom $45915(65 \%)$ had had at least one cervical smear test before the end of February 1971, when entry to the study was terminated. ${ }^{2}$ This analysis is based on 45266 women of known age who had not had hysterectomy, treated invasive cancer of the cervix, or other gynaecological cancer.

\section{CYTOLOGY}

Smears were taken with a wooden spatula and stained by the Papanicolaou technique. The quality of the smears was assessed as good, poor, or useless. In the latter case repeat samples were requested. Both good and poor quality smears were classified on a five-point scale as: normal (none of the following); atypical (changes of the order seen in inflammation); dyskaryosis (irregularities in size, shape, and chromatin pattern of nucleus-subdivided as mild, moderate, or severe); suspicious (changes considered suspicious of malignancy); and positive (changes characteristic of malignancy).

\section{PREVALENCE TEST AND RESULT}

The prevalence test was defined as the first cervical smear test performed between 1965 (when the study began) and February 1971 (when entry to the study closed). For $96 \%$ of women this was their first known smear. About 4000 had at least one repeat test within three months of their prevalence test, either as part of a reproducibility study or to confirm an abnormal smear. To take account of these repeat smears the cytological prevalence result was defined as the worst cytological appearances at or within three months of the prevalence test.

\section{CLINICAL MANAGEMENT}

The recall system and initial management have been described ${ }^{1}$ but are summarised here. Any woman in whom a gynaecological abnormality was detected (whatever the smear result) was referred either to her general practitioner-for example, for minor infections-or, if there was any suspicion of gynaecological malignancy, direct to the gynaecologist. In the absence of clinically evident pelvic disease the following recall programme was used.

Normal cytological appearance-Repeat smear after two to three years. 
Atypical cytological appearance-Annual recall.

Dyskaryosis-Recall to a reassessment clinic within one month. Women with persistent dyskaryosis were recalled at intervals of three or six months depending on the degree of dyskaryosis. The decision to recommend further investigation or treatment was based on several factors, including the degree and duration of dyskaryosis.

Suspicious or positive smears-Recall to a reassessment clinic within one month. If the original classification was confirmed surgery was recommended. Further management rested with the gynaecologist under whom the patient was admitted. In the absence of other disease cone biopsy of the cervix was the usual initial procedure. If other disease was present or, in some cases, when sterilisation was requested hysterectomy was used more commonly. From June 1970 increasing use was made of colposcopy and local biopsy as an alternative or before more extensive surgery.

\section{INITIAL HISTOLOGY}

Tissue for histological examination was available from hysterectomy, cone, and punch samples, and the prevalence of histological samples in different cytological categories was not a direct indication of attitudes to clinical management of each category. The interval between cytological and histological examinations depended on the initial cytological findings and the indication for operation. For our study we report the histological findings within two years of prevalence testing. Histological findings were classified as: normal or no relevant significant abnormality; dysplasia (mild or moderate-CIN I and II); carcinoma in situ (including severe dysplasia-CIN III); microinvasive carcinoma (including borderline invasion); occult invasive carcinoma (histological evidence only of invasion); and clinically invasive carcinoma (macroscopic invasion).

TABLE I-Prevalence (per 1000 women) of various cytological categories

\begin{tabular}{|c|c|c|c|c|c|}
\hline \multirow[b]{2}{*}{$\underset{\text { (years) }}{\text { Age }}$} & \multicolumn{4}{|c|}{ Cytological category } & \multirow[b]{2}{*}{$\begin{array}{l}\text { Total No } \\
\text { of women }\end{array}$} \\
\hline & Normal & Atypical & Dyskaryosis & $\begin{array}{l}\text { Suspicious } \\
\text { or positive }\end{array}$ & \\
\hline $\begin{array}{l}25- \\
30- \\
35- \\
40- \\
45- \\
50- \\
55- \\
60- \\
\geqslant 65\end{array}$ & $\begin{array}{l}878 \cdot 5 \\
898 \cdot 4 \\
898 \cdot 4 \\
890 \cdot 2 \\
873 \cdot 8 \\
893 \cdot 4 \\
920 \cdot 6 \\
924 \cdot 4 \\
925 \cdot 3\end{array}$ & $\begin{array}{r}106.7 \\
90.1 \\
87.9 \\
95.0 \\
108.8 \\
92.8 \\
65.2 \\
65.0 \\
62.3\end{array}$ & $\begin{array}{r}10 \cdot 2 \\
6.7 \\
4.9 \\
6.7 \\
6 \cdot 2 \\
4.9 \\
4.6 \\
2.6 \\
3.7\end{array}$ & $\begin{array}{r}4 \cdot 6 \\
4 \cdot 7 \\
8 \cdot 8 \\
8 \cdot 1 \\
11 \cdot 2 \\
9 \cdot 0 \\
9 \cdot 6 \\
8 \cdot 1 \\
8 \cdot 8\end{array}$ & $\begin{array}{l}9175 \\
6823 \\
6566 \\
6313 \\
5342 \\
4107 \\
3235 \\
2340 \\
1365\end{array}$ \\
\hline $\begin{array}{l}\text { Total No } \\
\text { of women }\end{array}$ & 40450 & 4181 & 293 & 342 & 45266 \\
\hline
\end{tabular}

TABLE II-Age-specific prevalence (per 1000) of mild, moderate, and severe dyskaryosis

\begin{tabular}{|c|c|c|c|c|}
\hline \multirow{2}{*}{$\underset{\text { (years) }}{\text { Age }}$} & \multicolumn{3}{|c|}{ Degree of dyskaryosis } & \multirow{2}{*}{$\begin{array}{l}\text { Total No } \\
\text { of womer }\end{array}$} \\
\hline & Mild & Moderate & Severe & \\
\hline $\begin{array}{l}25-34 \\
35-44 \\
45-54 \\
55-69\end{array}$ & $\begin{array}{l}3.9 \\
2.4 \\
1.9 \\
1.3\end{array}$ & $\begin{array}{l}2.7 \\
1.4 \\
1.5 \\
1.4\end{array}$ & $\begin{array}{l}1.7 \\
1.0 \\
1.2 \\
0.7\end{array}$ & $\begin{array}{r}15998 \\
12979 \\
9449 \\
6940\end{array}$ \\
\hline $\begin{array}{l}\text { Total No } \\
\text { of cases* }\end{array}$ & 120 & 85 & 56 & 45266 \\
\hline
\end{tabular}

* Excludes 32 women for whom degree of dyskaryosis was not recorded.

\section{Results}

PREVALENCE

The prevalence of suspicious or positive smears increased with age to a maximum of $11 \cdot 2 / 1000$ in the age group $45-49$ and then decreased slowly (table I). The prevalence of dyskaryotic smears was highest $(10 \cdot 2 / 1000)$ in the youngest age group (25-29), and then decreased with age. The prevalence of atypical smears was noticeably lower in women aged 55 and over than in the younger age groups.

The degree of dyskaryosis was recorded in $89 \%$ of cases. In these it was classified as mild in $46 \%$, moderate in $33 \%$, and severe in $21 \%$ Table II shows the age-specific prevalence for each degree. The change of prevalence with age was similar for all three categories, with the highest prevalence in the youngest and lowest in the oldest age group.

\section{CYTOLOGICAL ABNORMALITIES AND HISTOLOGICAL FINDINGS}

Cervical tissue was obtained for histological examination within two years in $97 \%$ of women with suspicious or positive smears, $63 \%$ with severe dyskaryosis, $46 \%$ with moderate dyskaryosis, and $28 \%$ with mild dyskaryosis (table III).

TABLE IV-Histological findings in women with suspicious or positive smears*

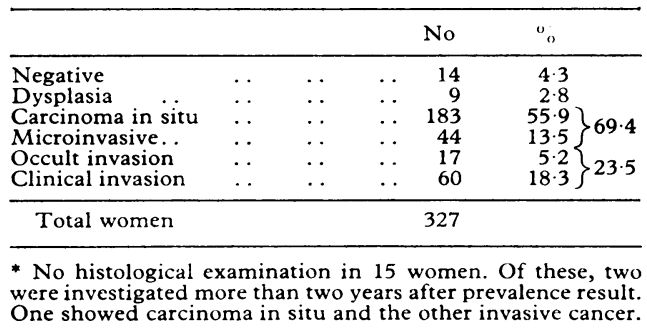

Suspicious or positive smears-Of the 342 women with suspicious or positive smears, only 15 were not investigated initially. Of these, two were subsequently investigated (after two years), one having carcinoma in situ and the other having invasive cancer; two had metastatic spread from carcinoma of the colon; four, after the initial suspicious or positive smear, had subsequent tests which were consistently normal; and seven refused further smears or biopsy or moved out of the area and were lost to follow-up. Table IV gives the histological findings in those with suspicious or positive results. In $93 \%$ of cases histological examination showed carcinoma in situ or worse.

Dyskaryotic smears-Two hundred and ninety-three women were found to have a dyskaryotic prevalence result (table III). Of these, 39 $(13 \%)$ were "lost" to follow-up smear testing after the first three months; 13 refused further tests, 24 moved out of the area, one died (not associated with cervical disease), and there was administrative failure to recall one. This left 254 women with a dyskaryotic prevalence result, who were followed up. Of these, 125 had a histological diagnosis within two years of the initial test (table V). Most presented at gynaecological outpatient departments with gynaecological disorders, and $75(60 \%)$ were admitted to hospital within six months of their first dyskaryotic result. These included the four women with clinical carcinoma and all those whose cytological smear patterns had deteriorated or showed persistent severe dyskaryosis. Carcinoma in

TABLE III-Number of women with dyskaryotic or suspicious or positive cytology at prevalence testing with histological diagnosis within two years

\begin{tabular}{|c|c|c|c|c|c|c|c|c|c|c|c|c|}
\hline \multirow[b]{3}{*}{ Age (years) } & \multicolumn{10}{|c|}{ Dyskaryosis } & \multirow{2}{*}{\multicolumn{2}{|c|}{$\begin{array}{l}\text { Suspicious or } \\
\text { positive }\end{array}$}} \\
\hline & \multicolumn{2}{|r|}{ Mild } & \multicolumn{2}{|c|}{ Moderate } & \multicolumn{2}{|c|}{ Severe } & \multicolumn{2}{|c|}{ Not recorded } & \multicolumn{2}{|c|}{ All dyskaryosis } & & \\
\hline & Total & $\begin{array}{c}\text { No (\%) } \\
\text { examined } \\
\text { histologically }\end{array}$ & Total & $\begin{array}{c}\text { No }(\%) \\
\text { examined } \\
\text { histologically }\end{array}$ & Total & $\begin{array}{c}\text { No }(\%) \\
\text { examined } \\
\text { histologically }\end{array}$ & Total & $\begin{array}{c}\text { No }\left(\begin{array}{c}\% \\
o\end{array}\right) \\
\text { examined } \\
\text { histologically }\end{array}$ & Total & $\begin{array}{c}\text { No }(\%) \\
\text { examined } \\
\text { histologically }\end{array}$ & Total & $\begin{array}{c}\text { No }\left(\begin{array}{c}(0 \\
0\end{array}\right) \\
\text { examined } \\
\text { histologically }\end{array}$ \\
\hline $\begin{array}{l}25-34 \\
35-44 \\
45-54 \\
55-69\end{array}$ & $\begin{array}{r}62 \\
31 \\
18 \\
9\end{array}$ & $\begin{array}{r}9(15) \\
12(39) \\
8(44) \\
4(44)\end{array}$ & $\begin{array}{l}43 \\
18 \\
14 \\
10\end{array}$ & $\begin{array}{r}18(42) \\
6(33) \\
8(57) \\
7(70)\end{array}$ & $\begin{array}{r}27 \\
13 \\
11 \\
5\end{array}$ & $\begin{array}{r}19(70) \\
5(38) \\
8(73) \\
3(60)\end{array}$ & $\begin{array}{r}8 \\
12 \\
10 \\
2\end{array}$ & $\begin{array}{l}3(38) \\
6(50) \\
8(80) \\
1(50)\end{array}$ & $\begin{array}{r}140 \\
74 \\
53 \\
26 \\
\end{array}$ & $\begin{array}{l}49(35) \\
29(39) \\
32(70) \\
15(58)\end{array}$ & $\begin{array}{r}74 \\
109 \\
97 \\
62 \\
\end{array}$ & $\begin{array}{r}70(95) \\
107(98) \\
91(94) \\
59(95)\end{array}$ \\
\hline All ages & 120 & $33(28)$ & 85 & $39(46)$ & 56 & $35(63)$ & 32 & $18(56)$ & 293 & $125(43)$ & 342 & $327(97)$ \\
\hline
\end{tabular}


situ or worse on histological examination was found in $8 \%$ of cases of mild dyskaryosis, $29 \%$ of cases of moderate dyskaryosis, and $38 \%$ of cases of severe dyskaryosis. One hundred and twenty-nine women with dyskaryotic smears were not subjected to operation within two years. Most had attended well-women clinics, and most were symptom free and were tested at three-monthly intervals for two years. Table $\mathrm{V}$ shows the subsequent cytological findings: $85(33 \%)$ were normal or atypical; $29(11 \%)$ were mainly atypical or normal but with an occasional dyskaryotic result; and $15(6 \%)$ had become suspicious or positive or were consistently dyskaryotic. All patients in the latter positive smears (tables IV and V). Though $51 \%$ of women with dyskaryotic smears were not subjected to operation initially, most of them were symptom free and followed up with repeated smear tests. We therefore assume that no important histological abnormality was missed, and the histological findings may be interpreted as percentages of all patients with dyskaryosis (table V). On this basis $22 \%$ of patients with dyskaryosis had carcinoma in situ or worse, including 3\% with occult or clinical invasion. In the absence of an early histological examination, however, all

TABLE $\mathrm{v}-$ Findings on following up women with dyskaryotic prevalence result. Figures are numbers of women (percentages in parentheses)

\begin{tabular}{|c|c|c|c|c|c|c|}
\hline \multirow{2}{*}{$\begin{array}{l}\text { State two years } \\
\text { after prevalence test }\end{array}$} & \multirow[b]{2}{*}{ Cytological/histological appearance } & \multicolumn{4}{|c|}{ Degree of dyskaryosis } & \multirow[b]{2}{*}{ Total } \\
\hline & & Mild & Moderate & Severe & Unknown & \\
\hline $\begin{array}{l}\text { Surgery, } \\
\text { histological } \\
\text { findings }\end{array}$ & $\left\{\begin{array}{l}\text { Normal } \\
\text { Dysplasia } \\
\text { Carcinoma in situ } \\
\text { Microinvasion } \\
\text { Occult invasion } \\
\text { Clinical invasion }\end{array}\right.$ & $\left.\begin{array}{c}24 \\
1 \\
7 \\
0 \\
0 \\
1\end{array}\right\}\left(\begin{array}{l}(1) \\
(1)\end{array}\right.$ & $\left.\begin{array}{r}10 \\
8 \\
18 \\
1 \\
1 \\
1\end{array}\right\}\left(\begin{array}{l}(14) \\
(11)\end{array}\right.$ & $\left.\begin{array}{rl}4 & (8) \\
12 & (22) \\
15 \\
1 \\
2 \\
1\end{array}\right\}(32)$ & $\left.\begin{array}{l}8 \\
1 \\
6 \\
2 \\
0 \\
1\end{array}\right\}\left(\begin{array}{l}(29) \\
(29)\end{array}\right.$ & $\left.\begin{array}{rl}46 & (18) \\
22 & (9) \\
46 \\
4 \\
3 \\
4\end{array}\right\}(20)$ \\
\hline $\begin{array}{l}\text { No surgery, } \\
\text { followed up } \\
\text { cytologically }\end{array}$ & $\left\{\begin{array}{l}\text { Normal or atypical smears } \\
\text { Occasional dyskaryotic smears } \\
\text { Consistently dyskaryotic or worse* }\end{array}\right.$ & $\begin{aligned} 53 & (51) \\
13 & (13) \\
4 & (4)\end{aligned}$ & $\begin{array}{rr}18 & (25) \\
8 & (11) \\
8 & (11)\end{array}$ & $\begin{array}{ll}6 & (12) \\
6 & (12) \\
3 & (6)\end{array}$ & $\begin{array}{ll}8 & (29) \\
2 & (7) \\
0 & \end{array}$ & $\begin{array}{ll}85 & (33) \\
29 & (11) \\
15 & (6)\end{array}$ \\
\hline Total & & 103 & 73 & 50 & 28 & 254 \\
\hline Lost to follow-up & None & $17 \quad(14)$ & $12 \quad(14)$ & $6 \quad(11)$ & $4 \quad(13)$ & (13) \\
\hline
\end{tabular}

- All 15 women had operation between two and seven years after prevalence test. Histological studies showed dysplasia (2), carcinoma in situ (12), and clinical invasion (1).

group subsequently had surgical treatment two to seven years after the prevalence test; and of these, two showed dysplasia, 12 had carcinoma in situ, and one had clinically invasive cancer.

\section{Discussion}

Other reports lack information on true prevalence rates for abnormal cervical cytological patterns. Our study highlights the differential in the age of the peak prevalence of the abnormal cytological categories. Suspicious or positive smears reached their highest prevalence in the 45-50 age group, while the prevalence of dyskaryotic smears was highest in the youngest age group. Atypical smears were commonest in women aged under 50 , suggesting that inflammatory conditions were more prevalent in the reproductive years.

The cytological finding of suspicious or positive cells was clearly regarded as an indication for ascertaining a histological diagnosis. Ninety-seven per cent of these women were subjected to operations within two years, and this policy was not influenced by age. The correlation between cytological and histological abnormalities in this group was high; $93 \%$ showed carcinoma in situ or worse, $2.8 \%$ showed dysplasia, and $4.3 \%$ were normal histologically. Of the latter, one subsequently developed invasive carcinoma of the cervix. In the study of Chao et $a l,{ }^{3}$ which related the cytological and histological findings in over 400 patients subjected to cone biopsy, grade IV and V smears (suggestive of carcinoma in situ or invasive carcinoma) were associated with carcinoma in situ or worse in $68.5 \%$ of cases, dysplasia in $24 \%$, and normal histological appearances in $7.5 \%$.

Forty-three per cent of women with dyskaryotic smears were submitted to biopsy or hysterectomy, and this was often because of other gynaecological disease. There was more ready recourse to operation with increasing severity of dyskaryosis (table III). Surgery was also more common in women over 45 , but this was largely due to the higher incidence of associated disorders (clinical cancer (4), postmenopausal bleeding (24), intermenstrual or postcoital bleeding (22), bleeding cervical polypi (2), menorrhagia with uterine fibroids (4)). We estimate that $60 \%$ of women with a histological diagnosis would have been subjected to surgery irrespective of the smear result.

The pattern of histological findings related to dyskaryotic smears was more variable than in the case of suspicious or such patients would have been subjected to further cytological examination within three to six months, and it is unlikely that women with microinvasion or occult invasion would be put at greatly increased risk by this delay. The four cases of overtly invasive carcinoma in this group were clinically evident at the first gynaecological examination, and absence of a suspicious or positive cytological result did not influence the clinical management.

In 203 patients with cytological evidence of dysplasia reported by Chao et al, ${ }^{3}$ cone biopsy showed carcinoma in situ or worse in $14 \%$, dysplasia in $57 \%$, and normal histological appearances in $29 \%$. In the Cardiff study, patients with dyskaryosis subjected to biopsy showed carcinoma in situ or worse in $46 \%$ cases, dysplasia in $18 \%$, and normal histological appearances in $31 \%$.

Relating the histological findings to the degree of dyskaryosis helps to provide guidelines for clinical management. Although the analyses presented here are based on the prevalence of cytological patterns, the decision to proceed to operation was often influenced by further smears showing a more severe cytological abnormality. On this basis carcinoma in situ or a worse histological result was found in $8 \%$ of cases of mild dyskaryosis, but in $29 \%$ of women with moderate and $38 \%$ with severe dyskaryosis. This emphasises the need for early repeat cytological or histological examination or both in all cases of dyskaryosis.

We thank all those who contributed to this study, especially the consultant gynaecologists and clinic staffs in South Glamorgan, epidemiologists, and field workers. The project has received financial support from the Department of Health and Social Security, the Welsh Office, the Medical Research Council, Tenovus, Cardiff Cancer Information Service, and Cardiff City Council.

\section{References}

${ }^{1}$ Landsman JB, Jones JM, Evans DMD, Sweetnam P. The Cardiff Cervical Cytology Study. Part 1-The organisation. Cardiff: Welsh Office, 1977.

2 Evans DMD, Hibbard BM, Jones JM, Landsman JB, Sweetnam P. The Cardiff Cervical Cytology Study. Enumeration and definition of population and initial acceptance rates. $\mathcal{F}$ Epidemiol Community Health $1980 ; 34: 9-13$.

${ }^{3}$ Chao S, McCaffrey RM, Todd WD, Moore JG. Conization in evaluation and management of cervical neoplasia. Am 7 Obstet Gynecol 1969;103: 574-84.

(Accepted 5 December 1980) 